\title{
KEBIJAKAN PUBLIK DALAM MENINGKATKAN PELAYANAN SEBAGAI IMPLEMENTASI OTONOMI DAERAH DI KOTA DENPASAR
}

\author{
I Nyoman Artayasa \\ Fakultas Ilmu Sosial dan Ilmu Politik Universitas Mahendradatta - Denpasar
}

\begin{abstract}
Abstrak- Kebijakan otonomi daerah terlahir dengan tujuan untuk menjaga pemerintahan dan keutuhan Negara Kesatuan Republik Indonesia (NKRI), dengan mendorong kemampuan prakarsa dan kreatifitas pemerintah daerah dan masyarakat daerah dalam mengejar kesejahteraan.Kebijakan publik adalah apapun pilihan pemerintah untuk melakukan atau tidak melakukan sesuatu. Hakekat pelayanan publik adalah pemberian pelayanan yang berkualitas kepada masyarakat yang merupakan perwujudan kewajiban aparatur pemerintah sebagai abdi masyarakat.Otonomi daerah memberikan kewenangan kepada pemerintah daerah dalam hal ini pemerintah kota untuk menggali potensi-potensi daerah untuk meningkatkan kualitas pelayanan kepada masyarakat.Dalam memberikan pelayanan yang baik kepada masyarakat, Pemerintah Kota Denpasar mengadopsi kearifan lokal yaitu falsafah Sewaka Dharma. Sewaka Dharma dapat diartikan sebagai "Melayani adalah Kewajiban."
\end{abstract}

\section{Kata Kunci: Kebijakan Publik, Sewaka Dharma, Otonomi Daerah}

\begin{abstract}
Policy of regional autonomy was born with the aim to keep the government and the integrity of the Unitary Republic of Indonesia (NKRI), by encouraging the ability of initiative and creativity of local government and local communities in the pursuit of prosperity.Public Policy is whatever governments choose to do or not todo. The principle of public service is to provide a service with a good quality to the community which embodies the obligation of the government apparatus as a public servant. Regional autonomy gives authority to local government in this case the city government to explore potential areas to improve the quality of service to the community. In providing good service to the community, Denpasar government adopt local wisdom that philosophy Sewaka Dharma. Sewaka Dharma can be defined as "Serving is the obligation."
\end{abstract}

Keywords: Public Policy, Sewaka Dharma, Local Autonomy 


\section{Pendahuluan}

Kebijakan atas otonomi daerah terlahir dengan tujuan untuk menjaga pemerintahan dan keutuhan Negara Kesatuan Republik Indonesia (NKRI), dengan caramendorong kemampuan prakarsa dan juga kreatifitas pemerintah daerah dan masyarakat daerah di dalam mengejar kesejahteraan. Otonomi daerah pada dasarnya bukan sebagai tujuan, melainkan alat ke dalam rangka terwujudnya cita-cita menuju keadilan, demokrasi, serta kesejahteraan rakyat.Otonomi daerah sangat erat berkaitan dengan demokrasi.Demokrasi mengatur suatu hubungan antara pemerintah dan masyarakat.Otonomi daerah mengatur hubungan antara pemerintah pusat dengan pemerintah daerah.Dalam negara kesatuan,diperlukan adanya keharmonisan kekuasaan pemerintah pusat dengan pemerintah daerah.

Kebijakan otonomi daerah membawa angin baru dan optimisme bagi daerah dalam mengatur dan mengurus terkait kepentingan masyarakatnya dan suasana baru hubungan pemerintah pusat dengan pemerintah daerah.Masyarakat di daerah yang selama ini lebih banyak pada posisi dimarginalkan, mereka selanjutnya diberikan kesempatan untuk bisa mendapatkan pengakuan dan penghargaan terhadap hak, aspirasi, dan kepentingannya. Melalui adanya kebijakan otonomi daerah ini, anggapan bahwa pemerintah lebih tahu kebutuhan masyarakat akan bergeser kepada masyarakatlah lebih mengetahui kebutuhan, aspirasi, dan kepentingannya sendiri.

Namun dalam perjalanannya seringkali terjadi pemahaman yang berbeda baik dari pemerintah pusat, pemerintah daerah, atau masyarakat itu sendiri. Keadaan ini sering mengaburkan semua harapan kita tentang masa depan kehidupan masyarakat, dimana hal dimaksud dipengaruhi karena pelayanan pemerintah kepada masyarakat yang lebih dikenal dengan pelayanan publik.

Hakekat pelayanan publik dimaksud merupakan pemberian pelayanan berkualitas kepada masyarakat luas sebagai perwujudan kewajiban aparatur pemerintah atau dikenal abdi masyarakat.Masyarakat setiap saat selalu menuntut suatu pelayanan publik yang berkualitas dari birokrat, meskipun tuntutan itu terkadang tidak sesuai dengan harapan, karena secara empiris pelayanan publik yang terjadi selama ini terkesan berbelit-belit, lamban, mahal, dan tergolong melelahkan.Kecendrungan demikiansering terjadi sebab masyarakat masih diposisikan sebagai pihak yang melayani bukan sebagai yang dilayani. 


\section{Permasalahan}

Berdasarkan pemaparan uraian di atas, permasalahan yang dihadapi adalah sebagai berikut:

1. Kebijakan publik yang bagaimana dapat meningkatkan pelayanan yang berorientasi pelayanan prima?

2. Bagaimana sumber daya manusia dalam memberikan pelayanan publik?

\section{Pengertian Kebijakan Publik dan Pelayanan Publik}

Hakekat kebijakan publikmerupakan apapun pilihan pemerintah untuk melakukan atau tidak melakukan sesuatu. Artinya 1) Kebijakan publik tersebut dibuat oleh badan pemerintah, bukan oleh organisasi swasta. 2) Kebijakan publik menyangkut pilihan yang harus dilakukan atau tidak dilakukan oleh badan pemerintah.

Perihal pelayanan publik sesuai dengan Undang-Undang Republik Indonesia Nomor 25 Tahun 2009 tentang Pelayanan Publik, pada pasal 1 ayat 1 disebutkan: Pelayanan publik adalah suatu kegiatan atau rangkaian kegiatan dalam hal pemenuhan kebutuhan pelayanan yang sesuai dengan peraturan perundang-undangan bagi setiap warga negara dan penduduk atas barang, jasa, dan

\section{Manfaat Penelitian}

1. Secara akademis dapat digunakan sebagai bahan masukan/referensi bagi pemerintah untuk membuat rencana dan strategi meningkatkan pelayanan kepada masyarakat di Kota Denpasar.

2. Secara praktik dapat memberikan masukan dalam upaya meningkatkan mutu pelayanan kepada masyarakat.

atau pelayanan administratif disediakan oleh penyelenggara pelayanan publik.

Hakekat dari pelayanan publik adalah pemberian pelayanan yang berkualitas untuk masyarakat, di mana merupakan perwujudan kewajiban aparatur pemerintah sebagai abdi masyarakat.

Pelayanan publik berkualitas, menurut Sinambela dalam bukunya judul; Reformasi Pelayanan Publik: Teori Kebijakan dan Implementasi, dapat dilihat dari beberapa indikator di bawah ini:

\section{Transparansi}

Dalam artian bersifat terbuka, mudah, dapat mampu diakses oleh semua pihak, disediakan secara memadai serta mudah dimengerti. 


\section{Akuntabilitas}

Dapat dipertanggungjawabkan sesuai dengan ketentuan peraturan perundangundangan yang berlaku.

\section{Kondisional}

Sesuai dengan kondisi dan kemampuan pemberi dan penerima pelayanan dengan tetap berpegang pada prinsip efisiensi dan efektifitas.

\section{Partisipatif}

Mendorong peran serta masyarakat dalam penyelenggaraan pelayanan pubik

\section{A. Pengertian Sewaka Dharma}

Sewaka Dharma sendiri dapat diartikan sebagai "Melayani adalah Kewajiban." Falsafah inilah yang ditanamkan kepada semua pegawai yang ada di Pemerintah Kota Denpasar, untuk memberikan layanan yang terbaik kepada masyarakat.Dengan Sewaka Dharma fungsi hakiki dari pemerintah Kota Denpasar adalah pelayanan (service) yang membuahkan keadilan, pemberdayaan yang mendorong kemandirian dan pembangunan menciptakan kesejahteraan rakyat.Semangat filosofiSewaka Dharma (melayani adalah

\section{B. Pengertian Otonomi Daerah}

Sesuai Undang-Undang Nomor 23 Tahun 2014 tentang Pemerintahan Daerah definisi otonomi daerah adalah sebagai dengan memperhatikan aspirasi

kebutuhan dan harapan masyarakat.

\section{Kesamaan hak}

Tidak diskriminatif dalam artian tidak membeda-bedakan suku, agama, ras, golongan, gender, dan status ekonomi.

\section{Keseimbangan hak dan kewajiban}

Pemberi dan penerima pelayanan publik harus memenuhi hak dan kewajiban masing-masing pihak.

kewajiban) sebagai motto pelayanan publik di Kota Denpasar, setidaknya dapat merubah mindsetkalangan aparatur di Kota Denpasar dari dilayani menjadi melayani

Pelayanan dengan Sewaka Dharma telah memberikan pengetahuan deskriptip-empiris untuk bisa memperkaya pemahaman dalam rangka upaya pengabdian oleh aparat Pemerintah Kota Denpasar.Sewaka Dharma adalah konsep pelayanan yang menekankan pada keselarasan antara pikiran, ucapan, dan tindakan pelayanan demi harmoni nilai-nilai kemanusiaan, kealaman, dan Ketuhanan.

berikut: Otonomi daerah merupakan hak, wewenang, dan kewajiban daerah otonom untuk dapat mengatur dan mengurus sendiri pemerintahan dan kepentingan masyarakat 
setempat sesuai dengan peraturan perundang-undangan.

Otonomi daerah pada dasarnya bukan tujuan, melainkan sebagai alat dalam rangka terwujudnya cita-cita keadilan, demokrasi, serta kesejahteraan rakyat.Otonomi daerah erat terkait dengan demokrasi.Demokrasi itu mengatur hubungan pemerintah bersama rakyatnya.Sementara itu, otonomi daerah mengatur hubungan antara pemerintah pusat dengan pemerintah daerah.Di dalam negara kesatuan perlu adanya keharmonisan antara kekuasaan pihak pemerintah di pusat dengan pemerintah daerah.

Daerah otonom, selanjutnya disebut daerah adalah kesatuan masyarakat hukum yang mempunyai batas-batas wilayah yang berwenang mengatur dan mengurus urusan pemerintahan dan kepentingan masyarakat setempat menurut prakarsa sendiri berdasarkan aspirasi masyarakat dalam suatu sistem Negara Kesatuan Republik Indonesia.

\section{PEMBAHASAN}

\section{A. Kebijakan Publik di Kota Denpasar.}

Kota Denpasar pada mulanya merupakan pusat Kerajaan Badung yang akhirnya menjadi Pusat Pemerintahan Kabupaten Daerah Tingkat II Badung, bahkan mulai tahun 1958 Denpasar dijadikan pula Pusat pemerintahan Propinsi
Dampak positif otonomi daerah adalah dengan otonomi daerah maka pemerintah daerah akan mendapatkankesempatan untuk menampilkan identitas lokal yang ada di masyarakat. Berkurangnya wewenang dan kendali dari pemerintah pusat mendapatkan respon tinggi pemerintah daerah dalam menghadapi masalah-masalah yang berada di daerahnya sendiri. Bahkan dana yang diperoleh lebih banyak dibandingkan yang didapat melalui jalur birokrasi di pemerintah pusat. Dana itu memungkinkan pemerintah lokal mendorong pembangunan daerah serta membangun program promosi kebudayaan dan pariwisata dengan melakukan otonomi daerah maka kebijakan dari pemerintah akan lebih tepat sasaran, hal tersebut dikarenakan pemerintah daerah cenderung lebih mengerti keadaan dan situasi daerahnya, serta potensipotensi unggul yang ada di daerah daripada pemerintah pusat.

Daerah Tingkat I Bali. Pada Tahun 1978 Kota Denpasar menjadi Kota Administratif dengan luas wilayah $123,98 \mathrm{~km}^{2}$ dengan jumlah penduduk pada saat terbentuknya 206.059 jiwa dan tingkat pertumbuhan penduduk saat itu 3,5\% per tahun. Dalam perkembangannya dilakukan reklamasi Pulau Serangan yang menambah luas Kota 
Denpasar lagi $3,80 \mathrm{Km}^{2}$, sehingga luas Kota Denpasar saat ini adalah: 127,78 $\mathrm{km}^{2}$. Kemudian dengan Undang-Undang nomor 1 Tahun 1992, maka terbentuklah Kotamadya Daerah Tingkat II Denpasar, yang telah diresmikan oleh Menteri Dalam Negeri pada tanggal 27 Februari 1992. Momentum ini merupakan babak baru dalam pemerintahan Kotamadya Dati II Denpasar.

Dengan berlakunya Undang-Undang nomor 22 Tahun 1999 tentang Pemerintahan Daerah, maka sebutan Kotamadya Daerah Tingkat II Denpasar berubah menjadi Kota Denpasar. Kota Denpasar terdiri dari 4 (empat) kecamatan yaitu Kecamatan Denpasar Barat, Kecamatan Denpasar Utara, Kecamatan Denpasar Timur dan Kecamatan Denpasar Selatan. Jumlah penduduknya saat ini adalah sebanyak : 680.919 jiwa. Dengan jumlah tingkat kepadatan penduduk 5.329 jiwa/Km².

Pelaksanaan Otonomi Daerah dapat dijadikan sebagai acuan dalam pelaksanaan pelayanan publik di Kota Denpasar yang nantinya dapat meningkatkan kesejahteraan masyarakat.Inovasi pelayanan publik di Kota Denpasar sebagai salah satu upaya meningkatkan kinerja pelayanan publik.

Di dalam memberikan pelayanan yang baik kepada masyarakat, Pemerintah Kota Denpasar mengadopsi kearifan lokal yaitu falsafat Sewaka Dharma. Sewaka Dharma dapat diartikan sebagai "Melayani adalah Kewajiban." Falsafah ini yang ditanamkan pada semua pegawai yang ada di PemerintahKota Denpasar, dalam memberi pelayanan terbaik kepada masyarakat.Dengan Sewaka Dharma fungsi hakiki pemerintah dari Kota Denpasar adalah pelayanan (service) yang membuahkan keadilan, pemberdayaan yang mendorong kemandirian dan pembangunan menciptakan kesejahteraan rakyat.

Pelayanan dengan Sewaka Dharma telah memberikan banyak pengetahuan deskriptipempiris untuk memperkaya pemahaman diri dalam rangka pengabdian aparat Pemerintah Kota Denpasar.Sewaka Dharmaini adalah konsep pelayanan yang menekankan pada keselarasan pikiran, ucapan, dan tindakan pelayanan demi harmoni nilai kemanusiaan, kealaman, dan Ketuhanan.

Layanan publik lewat semangat sewaka dharma diimplementasikan dengan wujud nyatanya dengan $3 \mathrm{~S}, 3 \mathrm{~K}$ dan $1 \mathrm{E} .3 \mathrm{~S}$ disini dimaksudkan adalah Senyum, Sopan dan Sungguh-sungguh.Artinya dalam memberi pelayanan kita haruslah menampilkan kesan pertama dengan perilaku keramahan yang mana ditampilkan dengan senyum.Dalam melayani kita harus mengedepankan sopan santun dan tidak memilih, tanpa memandang 
siapa yang kita layani. Dalam memberikan pelayanan untuk masyarakat,kita juga harus sungguh-sungguh dalam arti kita memahami apa yang mesti kita kerjakan.

Kemudian $3 \mathrm{~K}$, disini dimaksudkan adalah Ketelitian, Kecepatan, dan Ketepatan. Ketelitian sangat penting sehingga layanan tidak boleh terkesan berbelit-belit, dan tidak berpotensi menimbulkan permasalahandibelakang hari.Pelayanan yang kita berikan kepada masyarakat harus cepat serta sesuai dengan SOP yang ada.Ketepatan dalam arti tidak ada permasalahan ataupun kesalahan dalam memberi layanan untuk masyarakat.

Kemudian yang terakhir adalah $1 \mathrm{E}$, yaitu Evaluasi.Semua hasil pelayanan yang kita berikan kepada masyarakat itu perlu kita evaluasi, untuk mengetahui dimana letak

\section{B. Sumber Daya Manusia (SDM) yang Membuat Kebijakan Publik}

Untuk dapat membuat kebijakan dan memberi pelayanan yang berkualitas maka diperlukan beberapa persyaratan yang mesti dipenuhi antara lain:

\section{a. Kapasitas SDM yangMemadai}

$\begin{array}{lr}\text { Kemampuan } & \text { pengetahuan, } \\ \text { keterampilan,pengalaman, } & \text { serta } \\ \text { didukung oleh sikap mental, } & \text { moral,loyalitas dan dedikasi dari }\end{array}$

kelemahansekaligus kekurangan kita selama memberikan pelayanan yang didasari atas semangat sewaka dharma.

Menjaga keutuhan Negara Kesatuan Republik Indonesia (NKRI) ini merupakan kewajiban kita semua.Salah satu caranya dengan membangun pelayanan publik yang dilandasi oleh semangat Sewaka Dharma. Otonomi daerah memberikan kewenangan kepada pemerintah daerah dalam hal ini pemerintah kota untuk menggali potensi daerah dan meningkatkan kualitas pelayanan kepada masyarakat. Semangat tidak hanya diinginkan tapi harus diciptakan.Semangat sewaka dharmaini ditanamkan di hati dan pikiran semua aparatur di Pemerintah Kota Denpasar, sehingga para pegawai berpotensi memberikan pelayanan yang terbaik kepada setiap masyarakat.

pegawai akansangat mendukung untuk terwujudnya kinerja pelayanan pegawai yang optimal.

\section{b. Rekruitmen yang Baik}

Untuk mendapatpegawai-pegawai yang berkualifikasi baik di dalam memberikan pelayanan,maka diperlukan mekanisme proses rekruitmen yang tertata benar.

\section{c. Pembinaan yang Memadai}

Untuk meningkatkan kualitas pelayanan, maka itu perlu pembinaan kapasitas diriyang terencana dan berkelanjutan. 


\section{d. Pengawasan Masyarakat}

Pengawasan masyarakat baik dilakukan oleh lembaga perwakilan rakyat, media

\section{PENUTUP}

\section{A. Kesimpulan}

1. Kebijakan publik dalam rangka meningkatkan Pelayanan yang ideal untuk Kota Denpasar adalah pelayanan publik dengan falsafah Sewaka Dharma yang berarti melayani adalah kewajiban.

2. Pelayanan publik dengan Sewaka Dharma diimplementasikan dengan 3S (senyum, sopan, dan sungguhsungguh), 3K (ketelitian, ketepatan dan kecepatan), 1 E (evaluasi).

3. Sumber daya manusia (SDM) yaitu penyelenggara pelayanan publik harus memadai, melalui rekruitmen

\section{DAFTAR PUSTAKA}

Dwijanto Agus,dkk, 2006. Reformasi Birokrasi Publik di Indonesia.Yogyakarta: Gadjah Mada University Press

Isran Noor, 2012. Politik Otonomi Daerah untuk penguatan

NKRI.PT.Profajar Jurnalism. ........., 2012. Isran Noor dalam Perspektif Media.PT Profajar Jurnalism. massa, LSM, dan juga masyarakat secara langsung secara terus menerus.

yang baik danmelalui pembinaanpembinaan, serta pengawasan yang terus menerus.

\section{B. Saran.}

1. Pemerintah Kota Denpasar supayasenantiasa menanamkan falsafah Sewaka Dharma dimaksud kepada semua pegawai yang ada di Kota Denpasar.

2. Semua pegawai di Kota Denpasar agar memahami dan melaksanakan falsafah Sewaka Dharma.

Lijan Poltak Sinambela, dkk, 2006. Reformasi Pelayanan Publik : Teori Kebijakan dan Implementasi. Jakarta: Bumi Aksara.

Media Sewaka Dharma, 2012. Pelayanan Publik Berbasis Kearifan Lokal,Denpasar : Bagian Organisasi Setda Kota Denpasar. 
Pemerintah Kota Denpasar, 2011.Selayang

Pandang Kota Denpasar.Denpasa

r: Pemerintah Kota Denpasar

Sudharta,Tjok Rai dan Gde Pudja MA,2000. Manawa Dharmasastra: Kompedi un Hukum Hindu, Jakarta: Balai Bahasa.

Sura, I Gede, dkk.2002.Kamus Istilah Agama Hindu. Denpasar: Pemerintah Provinsi Bali.

Syamsuddin Haris, 2005. Desentralisasi dan Otonomi Daerah: Desentralisasi,
Demokratisasi dan Akuntabilitas Pemerintahan Daerah.Jakarta : LIPI Press.

Undang-Undang Republik Indonesia Nomor 23 Tahun 2014 tentang Pemerintahan Daerah.

Undang-Undang Republik Indonesia Nomor 29 Tahun 2009 tentang Pelayanan Publik. 